\title{
Daytime Sleepiness and Its Relationship with Disease Activity and Emotional State in Patients with Ankylosing Spondylitis
}

\section{Ankilozan Spondilitli Hastalarda Gündüz Uykululuk Durumu, Hastalık Aktivitesi ve Duygu Durumu ile Ilișkisi}

\author{
(D) Özlem Altındağ, (D) Mazlum Serdar Akaltun, (D) Ali Gür \\ Gaziantep University Faculty of Medicine, Department of Physical Medicine and Rehabilitation, Gaziantep, Turkey
}

\begin{abstract}
Objective: This study aimed to evaluate sleep disturbance in patients with ankylosing spondylitis (AS) and to analyse the relationship between disease activity, anxiety/depression and pain level.

Materials and Methods: Disease activity was assessed using the Bath ankylosing spondylitis disease activity index (BASDAI), sleep disturbance was evaluated by the Epworth sleepiness scale (ESS), pain level was evaluated by the visual analogue scale and emotional state was evaluated by the Beck depression inventory (BDI), state-trait anxiety inventory (STAI) I and STAI II. Data were examined using independent samples t-tests and Pearson's correlation analysis.

Results: Daytime sleepiness, depressive mood and anxiety levels were higher in patients with AS than in healthy controls. The ESS score correlated with BASDAI, BDI, STAI I and STAI II. Patients with AS had a considerably impaired sleep quality compared with the healthy controls, and a strong correlation was found between sleep and mood. A positive correlation was also noted between disease activity/pain severity and sleep quality.

Conclusion: Measuring sleep quality and mood is important for the comprehensive evaluation of the health status of patients with AS, which could provide valuable evidence for improving the management of disease and treatment decisions.
\end{abstract}

Keywords: Ankylosing spondylitis, sleep disturbances, disease severity
Öz

Amaç: Bu çalışmanın amacı ankilozan spondilitte (AS) uyku bozukluklarını değerlendirmek ve hastalık aktivitesi, anksiyete/depresyon, ağrı düzeyi arasındaki ilișkileri incelemektir.

Gereç ve Yöntem: Hastalık aktivitesi Bath ankilozan spondilit hastalığ aktivite indeksi (BASDAI) ile, uyku bozukluğu Epworth uykululuk ölçeği (EUÖ) ile, ağrı düzeyi görsel analog ölçeği ile, duygusal durum Beck depresyon envanteri (BDE), durumluk-sürekli kaygı envanteri (STAl) ve STAI II ile değerlendirildi. Bu veriler, bağımsız örneklem t-testleri ve Pearson korelasyon analizi kullanılarak incelendi.

Bulgular: AS hastalarında gündüz uykululuk, depresif duygu durumu ve anksiyete düzeyleri sağlıklı kontrollere göre daha yüksekti. EUÖ; BASDAI, $B D E$, STAI I ve II ile korelasyon gösteriyordu. AS hastalarında kontrollere göre önemli ölçüde bozulmuş uyku kalitesi saptandı ve uyku ile duygu durum arasında güçlü bir ilişki vardı. Ayrıca, hastalık aktivitesi/ağrı şiddeti ve uyku kalitesi arasında pozitif bir korelasyon vardı.

Sonuç: Sonuçlarımız, uyku kalitesinin ve emosyonel durumun, AS hastalarının sağlık durumunun kapsamlı değerlendirmesinin önemli bir parçası olduğuna dikkat çekti. Bu bilgi, hastalığın yönetimini ve tedavi kararlarını iyileştirmede bazı değerli ipuçları sağlayabilir.

Anahtar Kelimeler: Ankilozan spondilit, uyku bozukluğu, hastalık şiddeti

\section{Introduction}

Ankylosing spondylitis (AS) is an inflammatory condition of unidentified cause that mainly affects the axial skeleton as well as the peripheral joints and extra-articular system (1). Eighty percent of patients with AS have back pain, difficulty to move and wake up at night, causing sleep interruptions. Also, sleep disorders have been reported to be linked with disease activity, limited mobility, altered quality of life, and depression (2-4). In AS, sleep disorders are common, including impaired sleep quality, insomnia, trouble in awaking, and obstructive sleep apnea syndrome (OSAS) (5-7). Since AS leads to spinal inflammation and posture deformity, it is likely to cause changes in sleeping posture and hence may result in sleep disorders (5). One possible reason for the lack of healing

Address for Correspondence/Yazışma Adresi: Prof. MD Özlem Altındağ, Gaziantep University Faculty of Medicine, Department of Physical Medicine and Rehabilitation, Gaziantep, Turkey

Phone: +905336253049 E-mail: ozaltindag@yahoo.com ORCID-ID: orcid.org/0000-0003-1119-2987

Received/Geliş Tarihi: 13.01.2021 Accepted/Kabul Tarihi: 08.03.2021

${ }^{\circ}$ Copyright 2021 by Turkish Sleep Medicine Society / Journal of Turkish Sleep Medicine published by Galenos Publishing House. 
achievement in AS may the very limited research conducted on the frequency and associations of sleep disorders in patients with AS. Sleep disorders might reduce the individual's quality of life by seriously disrupting the physical symptoms of cognition, mood, and diseases. Moreover, sleep changes increase the pathological significance of any disease and decrease complete well-being. According to our current knowledge, there is no study revealing the relationship between disease severity, sleep quality, and emotional state in AS patients.

When planning this study, it was considered whether the severity of disease in AS was directly related to sleep disturbances. We aimed to evaluate the frequency of daytime sleepiness and its relation to disease severity and emotional states in AS patients.

\section{Materials and Methods}

\section{Study design}

A total of 100 patients met the 1984 modified New York classification criteria for AS in 6 months (March-September 2020). Thirty-eight of 100 patients were on medication, 6 had infectious arthritis, and 4 were pregnant. Fifty-three AS patients (42 men, 11 women) were included in the study. Those with complaints of at least 6 months were included in the study. The 47 age- and sex-matched healthy controls (40 men, 7 women) were included in this case-control study. Before the study, Ethics Committee of Gaziantep University approved the study protocol (no: 2020/012). This study was performed by the principles of the Declaration of Helsinki. Written informed consent was attained from all participants.

Demographic characteristics, (age, gender, duration of illness, body mass index), and blood tests were recorded for each participant. The patients and controls who had malignancy, fibromyalgia, serious infections, or other systemic diseases were excluded from the study. Exclusion criteria were any co-existing disease or medication that may interfere with sleep. The entity of spinal kyphosis on a physical exam and serum C-reactive protein (CRP) and sedimentation rate were also recorded for all participants.

Daytime sleepiness, depressive mood, anxiety level were evaluated by Epworth sleepiness scale (ESS), Beck depression inventory (BDI), and state-trait anxiety inventory I-II (STAI 1 and STAI II) scales, respectively. Wholeness rating of pain score in AS patients was determined from a visual analog scale (VAS), recording from $0 \mathrm{~cm}$ (none) to $10 \mathrm{~cm}$ (very severe); Disease activity was assessed by Bath ankylosing spondylitis disease activity index (BASDAI).

\section{ESS}

ESS was used to determine the level of daytime sleepiness in the patients. ESS questions the general daytime sleepiness level of the individual, first proposed by Johns (8) in 1991 in the form of a simple questionnaire. It aims to evaluate falling asleep or falling asleep between 0-3 in eight different daily life situations. The total value, which is a maximum of 24 points, is determined as the patient's Epworth sleepiness score. Scores above 11 indicate daytime sleepiness. The reliability and validity of ESS in Turkish was assessed $(9,10)$.

\section{BDI}

$\mathrm{BDI}$ is a 21 -item self rating scale developed to measure severity of depressive symptoms. Participants score the severity of their symptoms that developed during the last 2 weeks on a 4-point Likert scale. Validity and reliability study of the Turkish form of BDI was performed by Hisli (11).

\section{STAI-II}

STAI contains two separate scales developed two measure state (STAI-I) and trait (STAI-II) anxiety levels (12). Responses to the questions stating severity of the feelings, thoughts and behaviours associated with state anxiety include "not at all, somewhat, moderately so, or very much so". Whereas the responses to the items related to trait anxiety include "almost never, sometimes, often, and almost always". Validity and reliability study of the Turkish form of the scale was performed by Öner and Le Compte (13).

\section{BASDAI}

The BASDAl consists of a one through 10 scale (one being no problem and 10 being the worst problem) which is used to answer 6 questions pertaining to the 5 major symptoms of AS (14). The Turkish version of the BASDAl was performed (15).

\section{Data Analysis}

Descriptive statistics were used for assessing the parameters related to the disease. The differences in terms of variables that are studied in patients and controls were evaluated with an independent sample t-test. The relations between the clinical parameters were examined with Pearson correlation analysis. $\mathrm{P} \leq 0.05$ were considered significant level.

\section{Statistical Analysis}

The analysis was performed by using the Statistical Package for the Social Sciences, version 17.0.1 for Windows (SPSS Inc., Chicago, U.S.A., 2008).

\section{Results}

The demographic and clinical characteristics of the patients are given in Table 1 . The mean age of the patients and controls were $33.4 \pm 7.4$, and $34.2 \pm 6.06$ years in respectively. There were no significant differences between patients and controls in respect to age and gender. The mean disease duration was $5.7 \pm 3.8$ years in patients. The mean value of serum ESR and CRP levels in patients was $21.9 \pm 18.0$ and $6.7 \pm 0.9$ in patients, respectively. ESR and CRP values were within normal limits in both groups. The mean ESS scores of the patients and controls were 12.2 $\pm 3.1,7.8 \pm 3.2$; the mean BDI scores of the patients and controls were $15.01 \pm 8.4$ and $7.4 \pm 5.6$; the mean STAI I

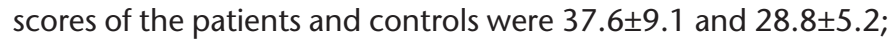
the mean STAI 2 scores of the patients and controls were

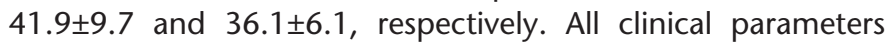
were significantly higher in patients with AS than in healthy controls $(p<0.001)$. ESS scores of $11-24$ were considered an increased level of "daytime sleepiness", $71.7 \%$ had severe or moderate daytime sleepiness. The mean VAS pain scores were $8.4 \pm 0.9$ and $3.0 \pm 1.0$ in patients and controls, respectively. The 
mean scores of BASDAl were $3.6 \pm 0.8$ and $1.9 \pm 1.1$ in patients and controls, respectively. The mean VAS pain and BASDAI scores were higher in the patient's group than in the controls $(p<0.001)$. Furthermore, the ESS score was correlated with BASDAI and VAS pain scores in the patient group $(p=0.005$, $r=0.380 ; p<0.001, r=0.563$, respectively), (Figure 1,2), (Table 2).

\section{Discussion}

In the present study, we have evaluated whether the disease severity in AS is directly related to daytime sleepiness. According to our observations, $71.7 \%$ had severe or moderate daytime sleepiness with ESS criteria, as expected. This ratio appears to be higher than the ratios reported in the general population (15-
$35 \%)$ (16). It was reported that sleep problems were important concerns in AS patients (The prevalence of OSAS in AS patients). A higher prevalence of OSAS patients with AS (12\%) than has been found in the general population (1-4\%) was reported. Limitation of the oropharyngeal air passage and restrictive pulmonary disease could be a facilitating factor to OSAS and lead to sleep disturbance in AS (17).

In the literature, there are only a few comprehensive studies investigating sleep disturbances in AS patients $(5,18)$, Therefore, We aimed to evaluate the prevalence of daytime sleepiness, which can shed light on the relation between AS and OSAS in AS patients. These promising data on the potential effect of disease severity with the determining of sleep disturbance strategy warrant further study.

\begin{tabular}{|l|l|l|l|}
\hline \multicolumn{2}{|l|}{ Table 1. Demographic and clinical features of patients with ankylosing spondylitis and healthy controls } \\
\hline & $\begin{array}{l}\text { Patients } \\
(\mathbf{n}=53) \\
\text { Mean } \pm \text { SD }\end{array}$ & $\begin{array}{l}\text { Healthy controls } \\
(\mathbf{n}=47) \\
\text { Mean } \pm \text { SD }\end{array}$ & p \\
\hline Age (year) & $33.4 \pm 7.4$ & $34.2 \pm 6.0$ & $>0.05$ \\
\hline Gender (E/K) & $39 / 14$ & $41 / 12$ & $>0.05$ \\
\hline $\begin{array}{l}\text { Disease duration } \\
\text { (year) }\end{array}$ & $5.7 \pm 3.8$ & - & - \\
\hline ESR & $21.9 \pm 18.0$ & $7.7 \pm 0.9$ & $<0.001$ \\
\hline CRP & $6.7 \pm 1.2$ & $5.6 \pm 2.8$ & $<0.001$ \\
\hline VAS pain & $8.4 \pm 0.9$ & $3.0 \pm 1.0$ & $<0.001$ \\
\hline BASDAI & $3.6 \pm 0.8$ & $1.9 \pm 1.1$ & $<0.001$ \\
\hline ESS & $12.2 \pm 3.1$ & $7.8 \pm 3.2$ & $<0.001$ \\
\hline BDI & $15.01 \pm 8.4$ & $7.4 \pm 5.6$ & $<0.001$ \\
\hline STAI I & $37.6 \pm 9.1$ & $28.8 \pm 5.2$ & $<0.001$ \\
\hline STAI II & $41.9 \pm 9.7$ & $36.1 \pm 6.1$ & $<0.001$ \\
\hline $\begin{array}{l}\text { STAI: State-trait anxiety inventory, SD: Standard deviation: CRP: C-reactive protein, ESR: Erythrocyte sedimentation rate, VAS: Visual analog scale, BASDAl: Bath } \\
\text { ankylosing spondylitis disease activity index, ESS: Epworth slepiness scale, BDI: Beck depression inventory }\end{array}$ & \\
\hline
\end{tabular}

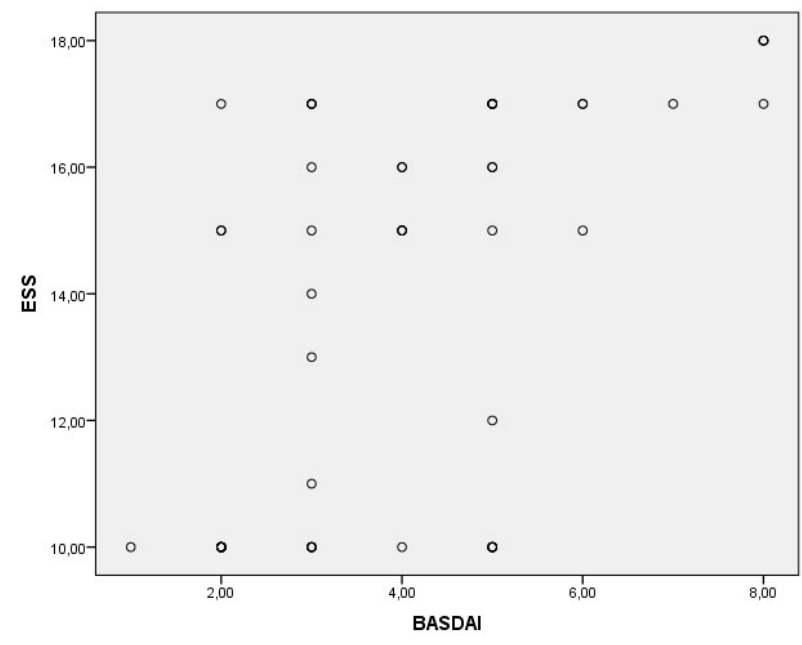

Figure 1. Correlation between BASDAI and ESS in patients with AS

BASDAI: Bath ankylosing spondylitis disease activity index, ESS: Epworth sleepiness scale, AS: Ankylosing spondylitis

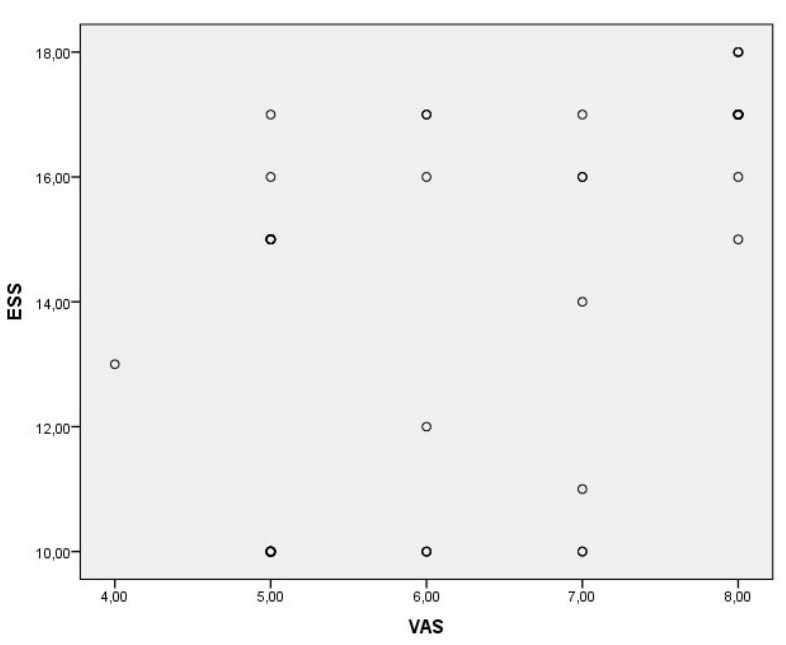

Figure 2. Correlation between VAS pain and ESS in patients with AS

VAS: Visual analog scale, ESS: Epworth sleepiness scale, AS: Ankylosing spondylitis 


\begin{tabular}{|l|l|l|}
\hline \multicolumn{2}{|l|}{ Table 2. Correlations between ESS and BASDAI and VAS pain in patients with Ankylosing spondylitis } \\
\hline & BASDAI & VAS pain \\
\hline \multirow{2}{*}{ ESS } & $\mathrm{p}=0.005$ & $\mathrm{p}<0.001$ \\
$\mathrm{r}=0.563$ \\
\hline ESS: Epworth sleepiness scale, BASDAI: Bath ankylosing spondylitis disease activity index, VAS: Visual analog scale \\
\hline
\end{tabular}

We have also observed that daytime sleepiness is influenced by pain and disease activity in patients with AS. It can be thought that poor posture in the body may affect the quality of sleep and cause daytime sleepiness (19). Symptoms of depression and anxiety are widespread in patients with chronic musculoskeletal pain $(20,21)$. It has been reported that depressive symptoms diminish the quality of sleep (22). Da Costa et al. (7) found that depression is independently associated with poor sleep quality, sleep duration, and efficiency in patients with SpA. The correlation between disease severity and sleep disturbance have suggested that sleep quality may be associated with functional disability and/or fatigue among patients with AS. These results may cause higher fatigue during the day and interrupted sleep at night, thus leading to sleep disorders. Also, the depression that develops as a result of the diminished daily living activities in the patients may give rise to sleep disorders. Hultgren et al. (5) have reported that the pain was the main reason for sleep disturbances in patients with AS. Similarly, we have observed that the pain level and disease activity is positively correlated with poor sleep quality.

It is not clear whether the sleep disturbance is related to clinical findings or the pathogenesis of the disease. The relationships between different clinical parameters require further investigation. However, it is possible that routine assessment for disturbed sleep beside the other clinical findings may be useful in the evaluation of disease activity and predicting future exacerbations. As a result, pharmacological or behavioral interventions may have a critical action on the health and lifetime of patients with AS.

In the study, we would like to emphasize another subject that high levels of anxiety and depression may result in damaging effects on the course of the disease, sleep quality, and healing process. AS is a chronic and devastating condition, and can lead to mood disorders.

AS and other rheumatic conditions have a negative effect on the quality of life. It has been shown that the poor quality of life and the limited functionality are correlated with depression and anxiety level. Sleep disorders also affect the quality of life and the psychological and physical function in adults with chronic pain syndromes $(23,24)$. Similarly, the diminished functionality in our study was closely related to poor sleep quality.

\section{Study Limitations}

There are several limitations to the present study. First, functional disability may affect depression, pain severity, and fatigue. It is probably that the relationships are bidirectional. Detailed research is needed to analyze the inter-relationships among these variables if causal associations are to be explained. Second, the present study only assessed sleep characteristics.
Further, different measures of sleep disturbances such as insomnia symptoms sleep duration, sleep performance and sleep disruption outcomes should have been assessed.

Third, our study had no direct measure of fatigue and thus we used the BASDAI subscale to assess fatigue.

Fourth, our study sample size was limited to the generalizability of the study findings to the general society. Even so, we think our results can provide important insights into this complex process by identifying relationships between clinical course and mood and daytime sleepiness in patients with AS.

\section{Conclusion}

Patients with AS had significantly higher daytime sleepiness compared to healthy subjects. Disease severity can probably impair patients' daily life events. Evaluation of parameters that may interact with disease severity should be considered as a vital part of a comprehensive assessment of the health status of these patients, and this can provide some valuable clues to improving disease management and treatment decisions.

\section{Acknowledgements}

This article was presented as an oral presentation at the $28^{\text {th }}$ International Congress of Physical Medicine and Rehabilitation held in Turkey, 8-11 April 2021.

\section{Ethics}

Ethics Committee Approval: The study was conducted in line with ethical principles, and was approved by the Ethics Committee of Gaziantep University, Ethics Committee in 2020 (06/01/2020-012).

Informed Consent: Written informed consent was attained from all participants.

Peer-review: Externally peer-reviewed.

\section{Authorship Contributions}

Concept: Ö.A., Design: Ö.A., Data Collection or Processing: A.G., M.S.A., Analysis or Interpretation: A.G., Writing: Ö.A.

Conflict of Interest: No conflict of interest was declared by the authors.

Financial Disclosure: The authors declared that this study received no financial support.

\section{References}

1. Zhu W, He X, Cheng K, Zhang L, Chen D, Wang X, Qiu G, Cao $X$, Weng $X$. Ankylosing spondylitis: etiology, pathogenesis, and treatments Bone Res 2019;7:22.

2. Batmaz I, Sarıyıldız MA, Dilek B, Bez Y, Karakoç M, Çevik R. Sleep quality and associated factors in ankylosing spondylitis: relationship with disease parameters, psychological status and quality of life. Rheumatol Int 2013;33:1039-45. 
3. Abad VC, Sarinas PSA, Guilleminault G. Sleep and rheumatologic disorders. Sleep Med Rev 2008;12:211-22.

4. Roizenblatt M, Rosa Neto NS, Tufik S, Roizenblatt S. Pain- related diseases and sleep disorders. Braz J Med Biol Res 2012;45:792-98.

5. Hultgren S, Broman JE, Gudbjörnsson B, Hetta J, Lindqvist U. Sleep disturbances in outpatients with ankylosing spondylitisa questionnaire study with gender implications Scand J Rheumatol 2000;29:365-69.

6. Taylor-Gjevre RM, Nair BV, Gjevre JA. Obstructive sleep apnoea in relation to rheumatic disease. Rheumatology (Oxford) 2013;52:15-21.

7. Da Costa D, Zummer M, Fitzcharles MA. Determinants of sleep problems in patients with spondyloarthropathy. Musculoskeletal Care 2009;7:143-61.

8. Johns MW. Rethinking the assessment of sleepiness. Sleep Med Rev 1998;2:3-15.

9. Izci B, Ardic S, Firat H, Sahin A, Altinors M, Karacan I. Reliability and validity studies of the Turkish version of the Epworth Sleepiness Scale. Sleep and Breathing 2008;12:161-8.

10. Agargun MY, Cilli AS, Kara H, Bilici M, Telcioglu M, Semiz UB, Basoglu C. Validity and Reliability of the Epworth Sleepiness Scale. Turk J Psychiatry 1999;10:261-7.

11. Hisli N. The validity and reliability of Beck Depression Inventory in university students. Turk J Psychol 1989;3-13.

12. Spielberger CD, Gorsuch RL, Lushene RE. Manual for State-Trait Anxiety Inventory. California: Consulting Psychologist Press 1970.

13. Öner N, Le Compte A. State-Trait Anxiety Inventory Handbook. Istanbul: Boğaziçi University Publications 1985.

14. Garrett S, Jenkinson T, Kennedy LG, Whitelock H, Gaisford P, Calin A. A new approach to defining disease status in ankylosing spondylitis: The Bath Ankylosing Spondylitis Disease Activity Index. J Rheumatol 1994;21:2286-91.
15. Ay S, Kutlay S, Kurtais Y, Yanik B. Adapdation and validation of the Turkish version of the bath ankylosing spondylitis disease activity index (BASDAI). Arch Rheumatol 2004;19:139-46.

16. Solak O, Fidan F, Dündar U, Türel A, Ayçiçek A, Kavuncu V, Ünlü M. The prevalence of obstructive sleep apnoea syndrome in ankylosing spondylitis patients. Rheumatology (Oxford) 2009;48:433-5.

17. Erb N, Karokis D, Delamere JP, Cushley M], Kitas GD. Obstructive sleep apnea as a cause of fatigue in ankylosing spondylitis Ann Rheum Dis 2003;62:183-84.

18. Zammit GK. The prevalence, morbidities, and treatments of insomnia. CNS Neurol Disord Drug Targets 2007;6:3-16.

19. Karadag O, Nakas D, Kalyoncu U, Akdogan A, Kiraz S, Ertenli I. Effect of anti-TNF treatment on sleep problems in ankylosing spondylitis. Rheum Int 2012;32:1909-13.

20. Woo AK. Depression and anxiety in pain. Rev Pain 2010;4:8-12.

21. Bao YP, Han Y, Ma J, Wang RJ, Shi L, Wang TY, He J, Yue JL, Shi J, Tang XD, Lu L. Cooccurrence and bidirectional prediction of sleep disturbances and depression in older adults: meta-analysis and systematic review. Neurosci Biobehav Rev 2017;75:227-57.

22. Jiang $Y$, Yang $M$, Lv Q, Qi J, Lin $Z$, Liao $Z$, Zhang $Y$, Wu $H$, Song $H$, Zhan F, Liu S, Gao G, Hu S, Li Y, Shen L, Huang A, Wei Q, Cao S, $\mathrm{Gu}$ J. Prevalence of psychological disorders, sleep disturbance and stressful life events and their relationships with disease parameters in Chinese patients with ankylosing spondylitis. Clin Rheumatol 2018;37:407-14.

23. Aydin E, Bayraktar K, Turan Y, Omurlu I, Tastaban E, Sendur OF. Sleep quality in patients with ankylosing spondylitis. Rev Bras Reumatol 2015;55:340-5.

24. López-Medina C, Garrido-Castro JL, Castro-Jiménez J, GonzálezNavas C, Calvo-Gutiérrez J, Castro-Villegas MC, Ortega-Castro R, Escudero-Contreras A, Font-Ugalde P, Collantes-Estévez E. Evaluation of quality of life in patients with axial spondyloarthritis and its association with disease activity, functionality, mobility, and structural damage Clin Rheumatol 2018;37:1581-8. 